\title{
The indispensable mental element of justification and the failure of purely objectivist (mostly "revisionist") just war theories
}

\author{
Uwe Steinhoff $(\mathbb{D}$
}

(C) The Author(s) 2020

\begin{abstract}
The "right intention" requirement, in the form of a requirement that the agent must have a justified true belief that the mind-independent conditions of the justification to use force are fulfilled, is not an additional criterion, but one that constrains the interpretation of the other criteria. Without it, the only possible interpretation of the mind-independent criteria is purely objectivist, that is, purely factrelative. Pure objectivism condemns self-defense and just war theory to irrelevance since it cannot provide proper action guidance: it is impractically demanding. This means that "revisionist" just war theories which base their doctrine of the moral inequality of combatants on the idea that objective justification defeats liability are irrelevant for the real world, where objective justification is virtually inaccessible. Moreover, only the right intention requirement in the form of a knowledge requirement, as opposed to requiring "good intentions" or "acceptable motivations," can solve this problem.
\end{abstract}

Keywords Just war theory $\cdot$ Knowledge requirement $\cdot$ Mixed account $\cdot$ Moral equality of combatants · Objective justification · Revisionism · Right intention · War

\section{Introduction}

Views on the just war criterion of "right intention" differ widely. Some just war theorists seem not even to be interested in the criterion. This is especially so for "revisionist" just war theorists, who rarely ever mention the criterion, and on those

\footnotetext{
U. Steinhoff $(\square)$

Department of Politics and Public Administration, University of Hong Kong, Pokfulam Road, Hong Kong, Hong Kong

E-Mail: ustnhoff@hku.hk
} 
rare occasions do so rather dismissively. ${ }^{1}$ Recently, moreover, the criterion has come under frontal and sustained attack, with three authors behind the attack proposing to discard it entirely (Purves and Jenkins 2016; Janzen 2016). ${ }^{2}$

Just war theorists writing more in a theological tradition, on the other hand, still deem the criterion highly relevant, and sometimes think that it should be interpreted expansively, that is, as also referring to motivations or even emotions, and not only to intention. ${ }^{3}$ They follow traditional just war theory, for in the tradition the criterion often covers both. While Aquinas says that "rightful intention" means to "intend the advancement of good, or the avoidance of evil," he quotes in support of this view an influential statement by Augustine referring to other mental states and not just to intention: "The passion for inflicting harm, the cruel thirst for vengeance, an implacable and relentless spirit, the fever of revolt, the lust of power, and such like things, all these are rightly condemned in war." (Aquinas ST II-II, q. 40, quoted from Reichberg, Syse, and Begby 2006, 177. Aquinas quotes Augustin, Contra Faustum, book XXII, art. 74.) Following Augustine and Aquinas, the later scholastics also seem to not clearly distinguish intention in the strict sense from "illicit" motivations and emotions. Thus in traditional just war theory, the term "right intention" has already been used to refer to more than merely intention. This, I submit, entitles me to also use it in a wider sense, namely as referring to yet another mental element: knowledge.

I will explain why the criterion of right intention - which applies both to jus ad bellum and jus in bello - must not be discarded if understood as proposed here, namely as a knowledge requirement (section 2). Conventional defenses of the right intention requirement argue that people have a right not to be killed with bad intentions (or on the basis of morally objectionable motivations, attitudes, or emotions, etc.); or they argue that even if people do not have such a right, it is nevertheless wrong to kill them if one does so with objectionable intentions or on the basis of bad motivations or emotions, etc. Thus, the right intention requirement is seen as a necessary addition to the other criteria. In contrast, my main argument runs considerably deeper. I argue that right intention is not a mere addition to the other criteria but actually a constraint on their interpretation. More precisely, my main argument is that without right intention, that is, without a subjective element in the justification to wage war, the only remaining option is a purely objectivist account of justification. (I reject both pure objectivism and pure subjectivism. My account is mixed.) Short of importing ad hoc assumptions into objectivist theory that are actually alien to it, however, objectivism can only come in the form of a strictly fact-relative account of justification (objectivist just war theorists actually tend to explicitly emphasize

\footnotetext{
1 All McMahan $(2005,5)$ has to say on the issue is: "It is not obvious to me that Right Intention is a valid requirement [for a just war]." Other "revisionists" seem to be equally dubious or even seem to take the irrelevance of the criterion for granted. For reasons why I use the term "revisionist" in scare quotes, see Steinhoff (2012a, section 2).

2 For a response to these authors, see Steinhoff (2018).

3 Clear examples are Biggar (2013) and Eberle (2016). Murphy (2014, 92-138), on the other hand, thinks that motives are at best relevant in an indirect way, but he does emphasize the importance of intention.
} 
the importance of fact-relative justification). ${ }^{4}$ But this poses a fatal problem: I will demonstrate that objectivist accounts of justification (or at least those that do not import ad hoc assumptions) lead to hyper-demanding just war criteria that cannot be intentionally followed and are therefore useless as action-guidance in the real world. Such purely objectivist criteria would also imply that real wars could never be objectively justified - unless by pure blind luck of cosmic proportions. Given that "revisionist" just war theory relies on an objectivist account of justification and on the credo that objective, fact-relative justification defeats liability to counter-attack (McMahan 2009, 43), which in turn serves as the foundation of the "revisionist" claim of the moral inequality of combatants (ibid., esp. 38-51), ${ }^{5}$ the impossibility (putting miracles aside) for any real war to ever be objectively justified means that revisionist just war theory and its inequality thesis are inapplicable to, and thus irrelevant for, the real world. ${ }^{6}$ In contrast, a just war theory incorporating the right intention requirement in form of a knowledge requirement - and only such a theory - can and does fulfill its action-guiding function.

To further bolster this result, in section 3 I will consider some objections to the argument I have just outlined and demonstrate that these objections fail. In fact, the curiousness of these objections is quite revealing in itself.

\section{The Indispensability of "Right Intention" in the Form of a Knowledge Requirement}

It is worthwhile to approach the issue of the right intention requirement in just war theory by comparing it to the parallel requirement in the ethics and law of selfdefense. To wit, in Anglo-Saxon law there is the Dadson principle (so named after a court case), according to which "justified force requires belief in, or knowledge of, the presence of justificatory circumstances" (Christopher 1995, 229). ${ }^{7}$ Anglo-Saxon

\footnotetext{
${ }^{4}$ Objectivism about justification is simply the view that a justification contains no mental element (like knowledge or right intention). That is compatible with appealing to notions of "objective probability" or to what an idealized observer would say. However, objectivists would then need to explain why one should not simply forget about probabilities and idealized observers and directly appeal to the facts (as, again, many objectivists explicitly do). I have nowhere found any plausible explanation for this; in fact, objectivists have so far not realized the impracticality problem that I describe below. In contrast, I straightforwardly explain why a knowledge requirement cannot simply be combined with a fact-relative account but instead constrains the interpretation of the objective criteria (foremost necessity).

${ }^{5}$ For a critique of McMahan's claims (as well as similar claims by others), see Steinhoff (2012a; 2016; 2020, sections 3 and 4.3.2). See also Hosein (2014; 2017).

${ }^{6}$ This is not to say that the thesis cannot be reformulated with the help of a mixed account, but such a reformulation will be more difficult than some might expect. However, the arguments made in the articles mentioned in the previous note would also apply to such a reformulation since they don't rely on the inequality thesis being formulated in fact-relative terms. Moreover, it should be noted that it would not inspire confidence if philosophers who first insist that only objective justification defeats liability suddenly change their mind in order to protect their preferred conclusions.

7 I have come across the objection that one could follow Walen in distinguishing acts from actions, so that the "act" may be "justified" or "permissible" without satisfying the Dadson principle while the "action" is not, and in that way have one's cake and eat it, as it were. However, one simply cannot have one's cake and eat it, and this case is no exception. See Steinhoff (2020, 196-197).
} 
law is not alone in requiring some subjective, i.e. mental, element for the justified use of force, including justified self-defense. It seems to be almost a consensus among Western jurisdictions that such a subjective element is required. ${ }^{8}$ The test case in the legal literature for the question whether the self-defense justification should contain a subjective element is the case of the unknowingly "justified" defender (I put "justified" in scare quotes because whether or not he or she is justified is precisely the contentious issue). Consider this example:

Jill and Earl: Jill always wanted to murder Earl, whose nose she does not like.

She sees him sitting in a restaurant, draws her gun, and shoots him dead. Unbeknownst to her, however, Earl, in turn, was just about to murder an innocent business rival who was also in the restaurant, and shooting Earl dead was the only way of preventing this.

The case of the unknowingly "justified" agent has been widely discussed in the legal literature, and while some authors - namely objectivists - would indeed deem Jill justified, the majority do not. ${ }^{9}$ Yes, with her action Jill actually saved the innocent person from an unjust attack. But did she really act in justified other-defense? That seems bizarre. True, she might have satisfied all the objective justificatory criteria of self-defense (that is, those not referring to mental states): there was Earl's imminent attack, and shooting Earl was (as we assume for now) necessary and proportionate under the circumstances. Yet Jill did not know that her act would preempt an unjust attack. She shot Earl simply to murder him and without any awareness of said justifying circumstances. Her act thereby demonstrated a blatant disregard for law and morality that, it seems, neither law nor morality can accept. Thus, it seems that we are not dealing with an act of justified self- (or other-) defense here.

Some objectivists, however, try to avoid the intuitively unacceptable result of letting Jill off the hook, so to speak, by trying to "get" Jill via an account of attempt liability. While Jill, according to this approach, engaged in justified self-defense and did not commit murder, she could still be held liable for attempted murder (Robinson 1975-1976, 291). Of course, the murder attempt - Jill's shooting Earl - is justified according to the objectivist, but Jill would still be culpable, and if culpability is sufficient for punishment, she could therefore be punished (Robinson 1996, 47-48; Hurd 2008, 263-264).

Yet, first, talking, about "culpable right action," as these objectivists do, seems highly counter-intuitive or even, as objectivists sometimes admit, "oxymoronic" (ibid., 263). Even more importantly, a second problem with this curious approach is that it is not clear what the objectivist means by "culpability." In particular, it is difficult to see how this could be moral culpability. Normally we say that someone is culpable if she knowingly or at least negligently did something that is

\footnotetext{
8 As Fletcher $(1978,557)$, states: "The consensus of Western legal systems is that actors may avail themselves of justifications only if they act with a justificatory intent." However, many Western legal systems seem to consider knowledge as sufficient. I argue elsewhere that it is indeed sufficient (Steinhoff 2020, section 2.2.5.4), but this point need not concern us here. The argument here is rather that it is necessary and cannot be replaced by specific intent or reference to motivations.

9 For overviews, see Sangero (2006, 217-237); Christopher (1995).
} 
in fact impermissible (and does not have an excuse). The objectivist cannot say that (on his account Jill's act is not impermissible). So why is Jill culpable? Maybe the objectivist will say that she is culpable because she recklessly took the risk of killing an innocent person, or that she is culpable because she knowingly did something that she thought to be impermissible (this latter account of impermissibility will let many ideologically motivated killers off the hook since they might think that they are even obliged to kill), or that she is culpable because she (mistakenly) thought that she did some act $\mathrm{x}$ and it is in fact the case (whether she thinks so or not) that doing $\mathrm{x}$ would be wrong. But why does that make her culpable on the objectivist account? After all, morality, on the objectivist account, does not require her not to be reckless in this way or not to do something she deems to be impermissible: if it did, then her act of shooting Earl would be impermissible (since it contravenes a requirement of morality), which, however, is precisely what the objectivist denies. To put it differently: if morality required people not to act culpably, then Jill's act would be impermissible. If however, as the objectivist claims, morality does not require people not to act culpably - on what basis can the objectivist claim that Jill is "morally culpable"? What does this even mean then? The objectivist does not really explain this. ${ }^{10}$

I think that this line of reasoning is correct. Admittedly, however, it relies heavily on our intuitions regarding this case. One attempt to do better has been undertaken by Russell L. Christopher (1994; 1995; 1998a; 1998b). He argues that a purely objectivist account of self-defense leads to logical contradictions. Yet, while Christopher's arguments are ingenious (and have no equivalent in the just war literature), they are open to severe doubts. ${ }^{11}$ Therefore I prefer not to rely on his arguments. My own argument, instead, is that a purely objectivist account leads to a hyper-demanding and thus entirely impractical, that is, useless - account of the necessity condition of self-defense.

Why is that? Well, there is no discernible reason why an objectivist account of justification should, in the context of self- and other-defense, understand "necessary" in any other way than as referring to literally and objectively the mildest means necessary to defend oneself or another from an attack. After all, the objectivist wants to talk about "fact-relative justification," where these facts are not supposed to refer to what people know or can know or reasonably assume. But then it is mysterious how, in real life, any actual instance of lethal self-defense could ever be necessary - and thus it is mysterious how it could ever be justified.

The reason for this is that it is a simple fact of physics that if Jill had fired a shot at a certain time $t$ while holding her weapon in a certain position $p$ the bullet of her gun would have struck the bullet coming out of Earl's gun in midair and deviated it in such a way as to save the life of Earl's innocent rival. Of course, there is no

\footnotetext{
${ }^{10}$ Incidentally, it seems to me almost deliberately obtuse to simply reiterate here that one is culpable for acting on the intention to do what would be objectively impermissible if the world were as the agent thinks it is. Again, if this is not immoral - whence the moral complaint?

${ }^{11}$ For some such doubts, see Dilloff (2002, 1558-1564) and Westen and Mangiafico (2003, 877, n. 92). Moreover, Rivera-López (2006) shows that some accounts of justified self-defense that include a subjective element also run into a logical contradiction. As it stands, therefore, I prefer not to rely on Christopher's arguments since I am not entirely convinced by them.
} 
way that Jill can know which time and position that is, but since we are talking about objective justification, this is irrelevant. Likewise, it is a fact of physics and physiology that if Jill had fired a shot at a certain time $t$ ' while holding her weapon in a certain position $p$ ', the bullet of her gun would have struck Earl's skull in such a way as to knock him unconscious. She also, less fancily, could have simply shot Earl's gun out of his hands. ${ }^{12}$ While objectivists can accept the "ought implies can" doctrine, they - unlike their opponents - cannot understand the "can" epistemically (as in: "She couldn't know) but at best physically and physiologically. But in this sense of "can" Jill could, objectively speaking, do all the things I have just described, and thus it was objectively unnecessary and unjustified for her to kill Earl.

This holds for virtually all cases of self-defense with a firearm, and it is no different for soldiers using firearms. It is also no different for artillery or missiles. In fact, if we are talking about war, for example against an aggressive dictator, it is mysterious why war should be objectively necessary at all. Why not just call the dictator, or otherwise communicate with him, and tell him all his secrets: "You have your bunkers there and there, they can be destroyed with a direct hit by this and this ammunition, you planned to go tomorrow there, and yesterday you were there, and ate this and this." If the dictator thinks he is an open book - and thus, more importantly, a sitting duck - to his enemy, then this will certainly make him very susceptible to negotiation (in fact, he will probably be scared out of his wits). Of course, the other side does not have this information, but that is irrelevant for the objectivist. After all, it is certainly physically and physiologically possible to say or write the right words to the dictator. ${ }^{13}$ Accordingly, there is always, objectively speaking, a method short of war. And thus objectivist accounts of justified selfdefense or of justified war limit the scope of these justifications in such a way that they give us no guidance for the real world and will render justified lethal (or even very harmful) self-defense and justified wars not only factually non-existent but practically (as opposed to logically, physically, and physiologically) impossible.

An important implication of this result is, as already mentioned, that it reduces McMahan's (and his followers') theory of the "moral inequality of combatants" to practical irrelevance. After all, his theory is based on the view that justification defeats liability to defensive attack (McMahan 2009, 43), which then would make justified soldiers non-liable (in contrast to their unjustified enemy), which in turn serves as the foundation of the "revisionist" claim of the moral inequality of combatants (ibid., esp. 38-51). ${ }^{14}$ Yet he makes clear that "justification provides exemption from liability only when it is objective," where the objectivity is solely based on

\footnotetext{
12 It is mistaken to claim that this is a question not of knowledge but of ability. She simply has the physical ability to do it (she can hold her hands in all kinds of positions), and she can practically and reliably do it if she knows what to do (knowledge, incidentally, need not be propositional): so if she knows how to hold the gun and when to pull the trigger then that is sufficient for her to do it. And this is so every time this happens to her (as long as she has the relevant knowledge). The dictator example in the next paragraph, which does refer to propositional knowledge, makes the point even clearer.

13 Thus, this example is clearly about knowledge. After all, if the person knows what to say, there is no problem of ability: people reliably have the ability to pick up a phone and to utter the sentences they want to utter.

14 See note 5.
} 
facts not having to do with the agent's beliefs (ibid., 43; see also McMahan 2013, 135 ; 2014a, 118-123). However, in the real world no state and no soldier (leaving aside astronomical blind luck) will ever be able to be objectively justified. To be sure, recently McMahan $(2018,435-437)$ has begun to talk about probabilities in the context of the necessity requirement. However, he fails to explain a) why an objectivist account, an account allegedly concerned with facts, should rely on probabilities in the first place, b) which account of probability he has in mind and why (propensity or frequentist, or something else?), and c) how, exactly, this appeal to probabilities is supposed to work. In other words, this sudden talk of probabilities is a recent import into McMahan's theory that is entirely alien to objectivism and cannot be explained by it. Thus, if one accepts McMahan's objectivist premises and takes them seriously - instead of watering them down with ad hoc addendasoldiers in the real world are all moral equals: they all use objectively unnecessary and thus unjustified means in objectively unnecessary and thus unjustified wars.

In contrast to objectivist accounts, the account defended here can explain the more lenient (and thus non-objectivist) contours of the necessity criterion ${ }^{15}$ of self-defense and of the proportionality criterion of just war theory (which combines elements that the ethics and law of self-defense keep distinct as necessity and proportionality) in a straightforward, theoretically consistent, and plausible manner. The knowledge requirement itself is the key. The argument, basically, is as follows. Morality must provide proper action guidance. A morality concerned with the rights of innocent people cannot, on pain of inconsistency, leave it to pure blind luck whether agents violate the rights of innocent people or not. Thus, proper action guidance must enjoin people to take reasonable precautions not to violate the rights of innocent people or at least not to violate them in such a way that the violation fails to be outweighed by the greater good achieved. However, taking reasonable precautions involves a mental state, it requires people to act reasonably. Accordingly, they must have a reasonable, that is justified belief that the other conditions of justified selfdefense are fulfilled. (These conditions strike a balance between the interests, and in particular the protection of the rights, of innocent defenders, innocent aggressors, and culpable aggressors [Steinhoff 2020, sections 2.2.1 and 2.2.4]). Such a justified belief is only a necessary, not a sufficient condition for justified self-defense or war, since a rights-violation committed on the basis of a reasonable belief is still a rights violation and hence unjustified (barring a lesser evil justification ${ }^{16}$ ). Whether there is an attack or not is a question of fact. And given that it is a factual question whether

\footnotetext{
15 The criterion I propose is the following: "A defender fulfills the necessity requirement of justified selfdefense if and only if he or she chooses a way of defending himself or herself that would in the eyes of a reasonable person under the conditions of the self-defense situation be (one of) the mildest means among those means that promise a safe, instant and conclusive defense against the attack or - if this is not possible under the circumstances - among those means that promise the best possible defensive results. The defender, however, is free (but not required) to forego the best defensive results for the purposes of choosing an even milder means even if this heightens his or her own risk of being harmed." That this is a non-objectivist criterion can be seen in the fact that it refers to a merely reasonable observer (where reasonability is partly defined by community standards), not to an omniscient one, and thus also not to all the facts. I have defended this criterion at length in Steinhoff (2020, section 2.2.2).
}

${ }^{16}$ However, plausible lesser evil justifications are mixed too - they refer to both certain facts and certain epistemic requirements. For details, see ibid., section 4.2. 
there is an attack, mere reasonableness is not enough. Therefore, my account is mixed: it requires justified true belief. ${ }^{17}$ That is the knowledge requirement.

Enter the principle that "ought" implies "can." The ought-implies-can principle does not help the objectivist account, since Jill can do the things which would amount to the objectively mildest defensive means. But the principle does enable the mixed account to derive a less demanding necessity principle, for while she can $d o$ what amounts to using the objectively speaking mildest means, she cannot know what that means is. Even if she accidentally does it or even if she takes a wild guess and correctly believes that a certain measure is the objectively mildest one, that still does not amount to a justified belief, and thus it does not amount to knowledge. Thus, if ought implies can and if there is a knowledge requirement of justified self-defense, then the necessity requirement must be formulated in such a way that the defender can know what necessity requires. And hence an account that includes a knowledge requirement can straightforwardly explain why the necessity requirement must not appeal to physical facts that are epistemically inaccessible to defenders. The objectivist account cannot and does not explain that.

\section{Objections to the Previous Argument}

I consider the previous argument to be a conclusive argument against objectivism in general and thus also against the practical relevance of McMahan's just war theory in particular. That it is indeed a conclusive argument is unwittingly confirmed by the nature of the objections that I have received..$^{18}$ Let us have a look.

One objection I have come across is that some people plausibly use the term "objectivism" in a different way and that therefore my attack on objectivism fails. ${ }^{19}$ However, I am not criticizing objectivism as defined by others, but as defined by McMahan, by me, and by the entire legal scholarship. It is non-responsive to object to the proposition that pigs can't fly by pointing out that with "pig" some people might be referring - however "plausibly" - to helicopters.

\footnotetext{
17 So yes, there is still a reference to objective facts (again: the account is mixed). But the truth the agent needs to know under the account presented here is in principle accessible because the knowledge requirement functions as a constraint on the range of facts the agent needs to know. There is no such constraint in the objectivist account. Thus, there is a difference between objectivity and objectivism.

18 These objections are all taken from the comments of "revisionist" critics who commented on a previous draft of this paper.

19 This particular critic seems fond of Lazar's definition of objective wrongfulness (and thus, implicitly, of objective justification). That is not a good choice. Lazar $(2015,6)$ says that an act "is fact-relative wrongful if it is wrongful in light of all the non-moral facts." Due to the "all," however, this definition inescapably succumbs to the anti-objectivist argument presented here. Moreover, the definition is unhelpful as far as definitions go. Unless the meaning of the second occurrence of "wrongful" is explained, the definition is uninformative. If it is to be understood in the fact-relative sense, it is circular. If, in contrast, it is to be understood in, for example, the belief-relative sense, then the definition would appear to be incoherent, to the extent that it is even intelligible. If, finally, Lazar, like Parfit, is relying on some ordinary understanding of wrongfulness, then it should be pointed out that Parfit (2011, esp. 159-160) acknowledges that the ordinary understanding is most certainly not the fact-relative one. But to say that an act is fact-relative wrongful if it is wrongful (in some sense that is not fact-relative) in light of all the non-moral facts does not make sense. Haque's $(2017,8)$ definition runs into exactly the same problems.
} 
So let me repeat: As defined here and in legal scholarship, objectivism about justification is simply the view that justification contains no mental element (like knowledge or right intention). ${ }^{20}$ As McMahan $(2009,43)$ puts it: "An act is objectively permissible or justifiable when what explains its permissibility or justifiability are facts that are independent of the agent's beliefs." And my argument against objectivism is that once you accept such a fact-relative account, then there is no reason - desperate ad hoc assumptions are not reasons - to exclude epistemically inaccessible facts from the equation. If the facts matter, and a knowledge requirement, in fact any mental element, is rejected - why then exclude facts from the equation only because you cannot know them? How can that possibly make sense; and why, therefore, shouldn't all facts have to be considered?

Moreover, McMahan $(2013,135)$ embraces the consideration of all facts also by referring to Parfit's definition of objective wrongness. According to that definition, some "act of ours would be wrong in the fact-relative sense just when this act would be wrong in the ordinary sense if we knew all of the morally relevant facts" (Parfit 2011, 150). It would appear, however, that someone who knows all the facts and thus knows what to say to a dictator in order to scare him to such an extent that she can achieve her just cause without having to wage a war and to collaterally kill innocent civilians, including babies and toddlers, would be acting wrongly if she waged war all the same, would it not? Thus, in Parfit's objective sense of wrongness, all practically possible wars in the real world will, given that we are not omniscient, always be fact-relatively wrong and hence fact-relatively unjustified - which means that in the real world McMahan's "fact-relative justification defeats liability" thesis has no scope of application in the context of war. ${ }^{21}$ It logically follows that his moral inequality of combatants thesis likewise has no context of application in the real world.

Nevertheless, allow me to also clarify that I, for one, actually am interested in "objective justification" in the sense of actual, real justification. Note also that one cannot simply avoid the issue by making a distinction between "subjective justification" and "objective justification" (and perhaps still other kinds of justification):22

\footnotetext{
${ }^{20}$ For a classic statement of objectivism in legal scholarship, see Robinson (1996). For a critique, see Steinhoff (2020, section 2.2.5).

${ }^{21}$ Nor in any other context, but this need not concern us for present purposes. But see Steinhoff (2020, section 2.2.5).

22 "Revisionists" are very fond of this distinction, which leads them to ignore the substantive issue and the possibility of a mixed account - although the mixed account of justified self-defense is the dominant one in Western jurisdictions. For a critique of the strategy of simply distinguishing different "senses" of "ought" that is equally applicable to "justified," see Zimmerman (2008, 6-8). Note also, as an aside, that Parfit never gives a straightforward answer to the question whether justification in "the ordinary sense" includes a mental element or not. In fact, he does not even ask the question. (His definitions of fact-relative, beliefrelative, and evidence-relative justification, remarkably enough, all explain these concepts with reference to someone who would be justified in the ordinary sense if he believed or knew something. But the way this is done does not amount to presupposing the necessity of a mental element for ordinary justification; it rather side-steps the issue. That is unsatisfactory.) Moreover, the substantive moral distinctions Parfit seems to be after can be made by using and combining concepts like justification, excuse, or rights-violation in their ordinary senses. Replacing them with extraordinary uses of the term "justification," therefore, leads only to confusion, not to clarification.
} 
one cannot answer substantive legal or moral questions simply by making distinctions. What we are interested in is moral justification, and moral justification either includes a subjective element or it does not. Obviously, I defend the view that a person is really justified in her self-defensive act only if she satisfies both the subjective element of the justification and the mind-independent elements (the contours of the mind-independent elements, again, are constrained by the mind-dependent element). Thus, my account is mixed; I do not make justification simply relative to the agent's epistemic situation. I am not talking about "belief-relative" justification. I reject (in accord with many, if not all, Western jurisdictions ${ }^{23}$ ) both pure objectivism and pure subjectivism. Objectivism and objectivity are not the same. I am criticizing objectivists. My argument is that a fact-relative account implies that the necessity condition has to be understood as referring to literally and objectively the physically and physiologically mildest means necessary to defend oneself or another from an attack. And therefore the fact-relative account, just like a pig, won't fly.

Another objection rejects my argument from the dictator example. Allegedly, this is a "bizarre" argument, for if the course of action described in the example would work against the dictator, this would only be on the basis of luck, not on the basis of ability in the standard sense. Using the example is therefore analogous to saying that a coin flipping machine could flip 100 heads in a row, using a fair coin. This, so the objection continues, might happen, but could not be chosen, and that, allegedly, is the relevant "could." This would-be analogy completely distorts what I am saying. To wit, what I am saying is actually like saying that a gambler who knows all the relevant facts, that is, who knows the sequence of heads and tails for the next 100 coin tosses, can reliably use his voice and choose to spell out what the sequence is and thereby make a fortune. Just as omniscience comes in handy for a gambler, omniscience comes in handy for a warrior. Thus, it is not my argument that is bizarre, but rather objectivism. It implies that waging justified war (and engaging in justified self-defense) is practically impossible under our actual epistemic conditions (where we do not know all the relevant facts), which is precisely my argument against objectivism.

A further objection seems to realize that the anti-objectivist argument advanced here might be potentially devastating for McMahan's theory, and in the absence of any viable counter-argument therefore reacts by creatively reinterpreting this theory - so that it no longer involves an objectivist account of justification. To wit, the objector claims that the "most plausible" interpretation of McMahan is that he is an objectivist about rights-forfeiture or liability, but would accept that the contours of the necessity requirement of the self-defense justification (and of other justifications) has to be constrained by a knowledge requirement in the way I suggest. However, that can only be "plausible" to someone who ignores what McMahan actually says. Nowhere in his entire work does McMahan ever talk about objective or fact-relative liability or rights-forfeiture, but he does talk about objective justification. Moreover, since McMahan (for instance 2009, 14; 2014b, 433; and in particular 2016, esp. 195-206) insists that the necessity requirement is internal to liability and considers both personal self-defense and defensive war against an aggressor to be covered by

\footnotetext{
23 See notes 8 and 9.
} 
a "liability-justification" (2013, 124; 2012, 138; 2014a, 115), he cannot consistently be a non-objectivist about the necessity requirement of such justifications while simultaneously being an objectivist about liability, can he? Finally, as already noted, McMahan repeatedly emphasizes that only "objective" or "fact-relative" justification defeats liability and takes this concept from Parfit, who in turn refers to omniscience (McMahan 2013, 135; Parfit 2011, 150). Thus, to claim, nonetheless, that he does not officially endorse an objectivist account of justification is simply false. This is certainly not changed by the fact that, as also already noted, in recent work McMahan (2018, 435-437) has imported talk about probabilities into his talk about justification. A genuinely fact-relative morality, however, will not base its judgments on secondary and derivative facts about the probability that something will come to pass but rather on the primary fact that it will pass (if it does). Or to put it another way: omniscient observers need not bother with probabilities - they know what will happen. Thus, if McMahan now combines an officially objectivist account with talk about probabilities, then this is simply incoherent. ${ }^{24}$ This is a further argument against McMahan's account, not for it.

Still another objection doubts the relevance of the argument. More precisely, it doubts that the argument presented here really undermines the moral inequality of combatants, since, so the objection goes, it is not clear that a person who uses excessive force for a good end is the moral equal of someone who uses it for a bad end. In reply, it should be noted that it is also "not clear" that the soldiers on one side all fight for good ends and the soldiers on the other all for bad ends. Defending civilians, babies, and toddlers on one's own side from excessive and unjustified harm, after all, seems to be a good end (Steinhoff 2012a, section 4.1). Furthermore it should be noted that McMahan's inequality thesis is the direct denial of Walzer's moral equality thesis. With this thesis Walzer did not claim that soldiers on both sides are moral equals in the sense that they are, for instance, equally good husbands or fathers, but in that they have "an equal right to kill" (Walzer 2000, $41) .{ }^{25}$ It is precisely this claim that McMahan $(2009,4)$ attacks with his inequality thesis. Translated into his language, McMahan denies that the "just combatants" and the "unjust combatants" are equally liable. However, he bases this denial on his premise that "the criterion of liability to attack in war is moral responsibility for an objectively unjustified threat of harm" (ibid., 35). Since, according to him, the "just combatants" pose justified threats while the "unjust" ones pose unjustified threats, the latter are liable and the former are not; relatedly, the latter can abide by jus in bello restrictions and the former cannot (ibid., 6).

Here the argument presented above comes in: in the real world, war and killing in war is always objectively, that is, in the fact-relative sense, unjustified because it

\footnotetext{
${ }^{24}$ This incoherence is also confirmed by the fact that after he has introduced the reference to probabilities all that McMahan comes up with is the (in terms of action-guidance quite uninformative) claim that "what the necessity constraint requires is that one choose, from among the proportionate defensive options, the one that is overall morally best" (McMahan 2918, 437). If what is "morally best" is to be assessed from the fact-relative perspective, then all the objections adduced above return. And if it is not to be assessed from a fact-relative perspective, then this kind of justification with this necessity constraint cannot defeat liability according to his own repeated assertion that only fact-relative justification can do so.

25 Obviously, Walzer means a liberty right.
} 
will always be objectively unnecessary. So in real wars in the real world opposing soldiers on both sides satisfy McMahan's criterion for liability to attack, that is, they will be morally responsible for posing unjustified threats of harm. ${ }^{26}$ That will make them all liable to proportionate and necessary counter-measures. Of course, no one will be able to actually apply merely necessary counter-measures ${ }^{27}$ - and thus they will all continue posing unjustified threats of harm and be equally unable to abide by jus in bello restrictions. So in a way McMahan's objectivism indeed undermines Walzer's inequality thesis as formulated: there is no equal right to kill here because there is actually no right to kill. But this is equality again. This then is what I mean with the inapplicability of McMahan's inequality thesis: the premise the thesis relies on - namely that one side is objectively justified in waging war and killing people - is never true in the real world. ${ }^{28}$

If my McMahan interpretation is correct, and my argument relevant to his account, but a "revisionist" would still like to object somehow, then he or she might opt for at least doubting the argument's originality. And indeed, one critic claims that my argument is unoriginal because authors like Seth Lazar and Daniel Statman have already pointed out that a literal interpretation of the necessity requirement is untenable since it leads to counter-intuitive implications. ${ }^{29}$ Yet we do not need Lazar and Statman to point this out - Western jurisdictions have never interpreted the necessity requirement literally. In fact, I have criticized Statman for misunderstanding how the necessity requirement is used in Western law (Steinhoff 2012b, $231 ; 2020,51-52) .{ }^{30}$ Fortunately, though, I do not simply make the argument that the necessity requirement must not be interpreted literally. That would indeed be unoriginal. Rather, I make the argument that objectivism cannot avoid embracing a literal interpretation of the necessity condition - at least not without importing ad hoc crutches that are entirely alien to objectivism - that therefore objectivism is wrong, and that therefore all arguments based on objectivism are also wrong, McMahan's argument for the moral inequality of combatants among them. These are four original arguments.

The last line of defense is to do exactly that - import ad hoc assumptions as crutches. If objectivism cannot stand - well, then let us just "qualify" it. One proposal that has been suggested to me in this context is to hold that a) morality cannot require agents to perform acts that are not among their options, and b) that an agent's options

\footnotetext{
${ }^{26}$ Could one somehow still get to unequal liability by positing unequal responsibility/culpability? If necessity is, as McMahan claims, internal to liability, certainly not. Second, even if one could do that: that would be a different argument from the one based on unequal justification. Moreover, such a move would appear to have no practical relevance unless it implies the justifiability of unequal treatment - which is not the case given that only objectively necessary counter-measures against liable persons are permissible anyway. Finally, variances in culpability/responsibility will not neatly correspond to sides in a conflict.

27 That I am not able to inflict necessary force on you does not imply that you are not liable to it. That you are liable to it only implies that you would not be wronged by it if I inflicted it on you. It implies absolutely nothing about my abilities.

28 Thus, the solution implied by McMahan's objectivism is pacifism. But while there are some good arguments for pacifism, an objectivist account of justification is not one of them.

29 The critic refers to Statman (2011) and Lazar (2012).

30 I have also, for other reasons, criticized Lazar's account. See Steinhoff (2020, 98-99).
}

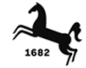


do not include acts that she does not know how to do. This proposal (apart, again, from being ad hoc and alien to objectivism) misses its mark. To illustrate this by using the dictator example again: an objectivist morality of war does not require you to stop the dictator by telling him secrets you do not know. Rather, given that you do not know how to do that, although that is the only thing objectivist morality would allow you to do given its interpretation of the necessity requirement, it requires you to do nothing. This, however, is not different from a situation where you can only stop an apple thief from escaping with your apple by killing him. Many "revisionists" deem it disproportionate to kill an apple thief. If that is correct but you do not know how to non-lethally stop the apple thief, then even non-objectivist morality requires you not to defend your property. Thus, the proposal does not succeed in blocking the conclusion not to fight when you do not know how to fight in the "objectively" justified way. Since no one can possibly know that, the only "option" here is pacifism. ${ }^{31}$

The most obvious crutch, however, is something else anyway. To wit, the objectivist might feel tempted to dilute the objectivist necessity requirement through the introduction of an objectivized reasonability requirement. ${ }^{32}$ This gives up the reference to an omniscient observer, and thus it actually leaves Parfit's understanding of objective justification behind, as well as McMahan's via his reference to Parfit. However, it does not give up on understanding objective justification as being at least independent of the mind of the agent. To wit, the idea of the objectivized reasonability requirement is that whether or not certain means are "necessary" would be determined from the standpoint of a reasonable observer or reasonable person in the defender's shoes. We do not need to dwell here on the details of such an account; the important point is simply that such an objectivized reasonability requirement makes the necessity requirement less harsh on the defender without introducing a subjective element into the necessity justification: that a reasonable observer would deem a shot in the attacker's chest reasonable or "necessary" under the circumstances is not the same as requiring that the defender himself act reasonably. In fact, it does not require any mental state on the part of the defender at all.

While such a maneuver would be logically perfectly consistent for the objectivist, it has to be said that not everything that is logically consistent also makes sense. If someone says, "I hate Paris, but I would really like to live there," then this is a logically coherent statement, but it is nevertheless rather odd and calls for an explanation. Likewise, if an objectivist about the self-defense justification reaches out for a reasonability requirement, even an objectivized one, one cannot help but wonder where this requirement is now suddenly coming from and how it fits into an objectivist account. After all, while the objectivized reasonability requirement does not refer to the mental states of the defender, it does refer to mental states (of a third

\footnotetext{
31 See note 28 .

32 Another possibility that might come to mind is to appeal to accounts of objective probability. This would amount to using the usual suspects: propensity accounts or frequentist accounts. I will not discuss this alleged possibility since I have to readily admit that I have not the slightest idea how one could even begin to make sense of it. However, if objectivists think that they can provide a plausible objectivist probabilistic rendering of the necessity requirement, then I would like to see it.
} 
party): but what are mental states doing in an objectivist account of the self-defense justification in the first place?

In other words, the problem is one of explanation. If the objectivist insists on fact-relative justification that is independent of the justified agent's mind - why then introduce the reference to someone's else's mind? What can possibly account for that - apart from the desperate desire to patch up a forlorn theory? Conversely, if there is a reference to the mind of a reasonable observer or reasonable person in the defender's shoes - why not go all the way and demand that the agent himself behave reasonably? Wouldn't that make sense? Qualified objectivists cannot explain any of this (they seem not even to realize that these are valid questions), nor other ad hoc assumptions they might wish to import into their "objectivism." Instead of a sound theory we get a patchwork of disconnected or even mutually incompatible ideas.

In contrast, again, the account presented here can explain what it needs to explain. To put it in a nutshell: Given that attacking people is prima facie wrong, is an offense, morality is only willing to extend the permission to do it anyway in certain circumstances if the would-be defenders know what they are doing. That, it would seem, is immensely reasonable and circumspect of morality. In contrast, to tell an agent that it is quite sufficient if he accidentally does what a reasonable person in his shoes would do seems to be rather confused and confusing advice, not advice given by a reasonable morality. Hence the knowledge requirement. Moreover, a reasonable morality, as opposed to a confused or even malicious one, does not give with one had what it takes away with the other. Thus, if it binds justification to a knowledge requirement, it must interpret the other requirements of a justification in such a way that it is in principle practically possible for the agent to know them. In principle. As already said, sometimes even reasonable people will fail. Reasonable people can make mistakes. Consequently a reasonable morality need not grant them guaranteed success. Nor, however, must it condemn them to guaranteed failure - as does objectivism. "Qualified objectivism," admittedly, does not, at least not necessarily. Just like qualified pregnancy it also does not make sense, though.

Let me finally also note that the needed explanation cannot be provided by what appears to be the standard account of the right intention requirement of just war theory. To wit, it is often said that in order to satisfy right intention the war has to be fought for the just cause, where the just cause is conceived of as some good end. ${ }^{33}$ Yet this account of right intention, by itself, cannot constrain the other just war criteria in such a way that they can provide action guidance. The reason for this is that the argument from the "ought implies can" principle does not work here - I can fight for a just cause (for example with excessive force) even if I do not know that the objective requirements are satisfied. Only the knowledge requirement can provide the needed constraint. Thus the standard account of right intention cannot really stave off the threat of pure objectivism and is therefore doomed to succumb

33 See, for instance, Coady (2008, 98-99); Fisher (2011, 72); Lee (2012, 83); O’Brien (1981, 34 and 166); Regan (1996, 85). 
to the very same problem of being practically useless. It would hence have to be amended with the knowledge requirement. ${ }^{34}$

\section{Conclusion}

The "right intention" requirement, in the form of a requirement that the agent must have a justified true belief that the objective, that is, the mind-independent conditions of the justification to use force are fulfilled, is indispensable for self-defense theory and just war theory. (Conditions can obviously be objective/mind-independent without being objectivist, that is, without being dependent on either epistemically entirely inaccessible facts or on omniscience.) It is not merely an additional criterion, but one that constrains the interpretation of the other criteria so as to keep them within the realm of the practically accessible and possible. To wit, without this criterion, the only possible interpretation - short of unwarranted ad hoc stipulations - of the mind-independent just war criteria is purely objectivist in the form of being purely fact-relative (or "omniscience-relative"). Pure objectivism, however, condemns just war theory to irrelevance since it cannot provide proper action guidance (and due to the limits of human knowledge it is also useless as an evaluative tool ex post): it is impractically demanding. This also means that "revisionist" just war theories which base their doctrine of the moral inequality of combatants on the idea that objective justification defeats liability are irrelevant for the real world, where objective justification is virtually inaccessible. Moreover, only the right intention requirement in the form of a knowledge requirement, ${ }^{35}$ as opposed to requiring "good intentions" or "acceptable motivations," can solve this problem. It is therefore necessary for just war theory. ${ }^{36}$

Funding The research presented in this article was supported by a grant from the Research Grants Council of the Hong Kong Special Administrative Region, China (Project No. HKU 17612817).

Open Access This article is licensed under a Creative Commons Attribution 4.0 International License, which permits use, sharing, adaptation, distribution and reproduction in any medium or format, as long as you give appropriate credit to the original author(s) and the source, provide a link to the Creative Commons licence, and indicate if changes were made. The images or other third party material in this article are included in the article's Creative Commons licence, unless indicated otherwise in a credit line to the material. If material is not included in the article's Creative Commons licence and your intended use is not permitted by statutory regulation or exceeds the permitted use, you will need to obtain permission directly from the copyright holder. To view a copy of this licence, visit http://creativecommons.org/licenses/by/4. $0 /$.

\footnotetext{
${ }^{34}$ Whether, conversely, the knowledge requirement needs to be amended with some good intention or good motivation requirement in order to have a full justification is a different question, which need not concern us here. For a negative answer, however, see Steinhoff (2020, section 2.2.5.4).

${ }^{35}$ Note that if one accepts that there are mind-independent requirements (for example the presence of an imminent attack in the case of the self-defense justification), justified belief cannot be enough, there must be justified true belief, and thus a knowledge requirement.

${ }^{36}$ The research presented in this article was supported by a grant from the Research Grants Council of the Hong Kong Special Administrative Region, China (Project No. HKU 17612817). I am very grateful for this support. I also thank Luciano Venezia and two anonymous referees of this journal for helpful comments.
} 


\section{References}

Biggar, Nigel. 2013. In Defence of War. Oxford: Oxford University Press.

Christopher, Russell L. 1994. Mistake of Fact in the Objective Theory of Justification: Do Two Rights Make Two Wrongs Make Two Rights ...? Journal of Criminal Law and Criminology 85(2): 295-332.

Christopher, Russell L. 1995. Unknowing Justification and the Logical Necessity of the Dadson Principle in Self-Defense. Oxford Journal of Legal Studies 15(2): 229-251.

Christopher, Russell L. 1998a. Self-Defense and Defense of Others. Philosophy \& Public Affairs 27(2): 123-141.

Christopher, Russell L. 1998b. Self-Defense and Objectivity: A Reply to Judith Jarvis Thomson. Buffalo Criminal Law Review 1(2): 537-574.

Coady, C. A. J. 2008. Morality and Political Violence. Cambridge: Cambridge University Press.

Dilloff, Anthony M. 2002. Unraveling Unknowing Justification. Notre Dame Law Review 77(5): 15471600.

Eberle, Christopher J. 2016. Justice and the Just War Tradition: Human Worth, Moral Formation, and Armed Conflict. New York and London: Routledge.

Fisher, David. 2011. War and Morality: Can War be Just in the Twenty-first Century? Oxford: Oxford University Press.

Fletcher, George P. 1978. Rethinking Criminal Law. Boston and Toronto: Little, Brown, and Company.

Haque, Adil Ahmad. 2017. Law and Morality at War. Oxford: Oxford University Press.

Hosein, Adam. 2014. Are Justified Aggressors a Threat to the Rights Theory of Self-Defense?' In Helen Frowe and Gerald Lang (eds.), How We Fight, 87-103. Oxford: Oxford University Press.

Hosein, Adam. 2017. Responsibility and Self-Defense: Can We Have It All? Res Publica 23(3): 367-385.

Hurd, Heidi. 2008. Moral Combat. Cambridge. Cambridge University Press.

Janzen, Greg. 2016. A Critique of the Right Intention Condition as an Element of Jus Ad Bellum. Journal of Military Ethics 15(1): 36-57.

Lazar, Seth. 2012. Necessity in Self-Defense and War. Philosophy and Public Affairs 40(1): 4-44.

Lazar, Seth. 2015. Sparing Civilians. Oxford: Oxford University Press.

Lee, Steven P. 2012. Ethics and War: An Introduction. Cambridge: Cambridge University Press.

McMahan, Jeff. 2005. Just Cause for War. Ethics and International Affairs 19(3): 1-21.

McMahan, Jeff. 2009. Killing in War. Oxford: Clarendon Press.

McMahan, Jeff. 2012. Targeted Killing: Murder, Combat, or Law Enforcement. In Claire Finkelstein, Jens David Ohlin, and Andrew Altman (eds.), Targeted Killings: Law and Morality in an Asymmetrical World, 135-155. Oxford: Oxford University Press.

McMahan, Jeff. 2013. The Conditions of Liability to Preventive Attack. In Deen K. Chatterjee (ed.), The Ethics of Preventive War, 121-144. Cambridge: Cambridge University Press.

McMahan, Jeff. 2014a. Self-Defense Against Justified Threateners. In Helen Frowe and Gerald Lang (eds.), How We Fight, 104-137. Oxford: Oxford University Press.

McMahan, Jeff. 2014b. Proportionality and Just Cause: A Comment on Kamm. Journal of Moral Philosophy 11: 428-453.

McMahan, Jeff. 2016. The Limits of Self-Defense. In Christian Coons and Michael Weber (eds.), The Ethics of Self-Defense, 185-210. Oxford: Oxford University Press.

McMahan, Jeff. 2018. Proportionality and Necessity in Jus in Bello. In Seth Lazar and Helen Frowe (eds.), The Oxford Handbook of the Ethics of War, 418-439. Oxford: Oxford University Press.

Murphy, James G. 2014. War's Ends: Human Rights, International Order, and the Ethics of Peace. Washington DC: Georgetown University Press.

O'Brien, William V. 1981. The Conduct of Just and Limited War. New York: Praeger.

Parfit, Derek. 2011. On What Matters, Volume One. Oxford: Oxford University Press.

Purves, Duncan and Ryan Jenkins. 2016. Right Intention and the Ends of War. Journal of Military Ethics 15(1):18-35.

Regan, Richard J. 1996. Just War: Principles and Cases. Washington, DC: Catholic University of America Press.

Reichberg, Gregory M., Henrik Syse, and Endre Bebgy (eds.). 2006. The Ethics of War: Classic and Contemporary Readings. Oxford: Blackwell.

Rivera-López, Eduardo. 2006. Puzzles on Defending Others from Aggression. Law and Philosophy 25: 377-386.

Robinson, Paul H. 1975-1976. A Theory of Justification: Societal Harm as a Prerequisite for Criminal Liability. UCLA Law Review 23: 266-292. 
Robinson, Paul H. 1996. Competing Theories of Justification: Deeds v. Reasons. In A. T. Simester and A. T. H. Smith (eds.), Harm and Culpability, 45-70. Oxford: Clarendon Press.

Sangero, Boaz. 2006. Self-Defence in Criminal Law. Oxford and Portland: Hart Publishing.

Statman, Daniel. 2011. Can Wars Be Fought Justly? The Necessity Condition Put to the Test. Journal of Moral Philosophy 8: 435-51.

Steinhoff, Uwe. 2012a. Rights, Liability, and the Moral Equality of Combatants. The Journal of Ethics 16(4): 339-366.

Steinhoff, Uwe. 2012b. The Nature and Scope of Self-Defense under Special Consideration of Killing in War. Filozofski Godišnjak (Philosophical Yearbook) 25: 207-234.

Steinhoff, Uwe. 2016. When May Soldiers Participate in War? International Theory 8(2): 262-296.

Steinhoff, Uwe. 2018. Right Intention: A Reply to Janzen, Purves, and Jenkins. Journal of Military Ethics 17(2-3): 172-176.

Steinhoff, Uwe. 2020. Self-Defense, Necessity, and Punishment. London and New York: Routledge.

Walzer, Michael. 2000. Just and Unjust Wars: A Moral Argument with Historical Illustrations, Third Edition. New York: Basic Books.

Westen, Peter and James Mangiafico. 2003. The Defense of Duress in Criminal Law: A Justification, Not an Excuse-And Why It Matters. Buffalo Criminal Law Review 6(2): 833-950.

Zimmerman, Michael J. 2008. Living with Uncertainty: The Moral Significance of Ignorance. Cambridge: Cambridge University Press. 